Rev. Bras. Saúde Prod. Anim., Salvador, v.13, n.1, p.192-203 jan/mar, 2012 http://www.rbspa.ufba.br ISSN 15199940

\title{
Fatty acids profile of milk from cows fed different maize silage levels and extruded soybeans
}

\author{
Perfil de ácidos graxos do leite de vacas alimentadas com diferentes níveis de silagem \\ de milho e grão de soja extrusado
}

\section{OLIVEIRA, Marcelli Antenor ${ }^{1}$; REIS, Ronaldo Braga ${ }^{1}$; LADEIRA, Márcio Machado RIBEIRO, Cláudio Vaz Di Mambro ${ }^{3}$; LOPES, Leandro Sâmia ${ }^{2}$; FRANCO, Gumercindo Loriano ${ }^{4}$; OLIVEIRA, Ronaldo Lopes ${ }^{3}$}

\footnotetext{
${ }^{1}$ Universidade Federal de Minas Gerais, Escola de Veterinária, Departamento de Zootecnia, Belo Horizonte, Minas Gerais, Brasil.

${ }^{2}$ Universidade Federal de Lavras, Departamento de Zootecnia, Lavras, Minas Gerais, Brasil.

${ }^{3}$ Ubiversidade Federal da Bahia, Escola de Medicina Veterinária, Departamento de Produção Animal, Salvador, Bahia, Brasil.

${ }^{4}$ Universidade Federal de Mato Grosso do Sul, Departamento de Zootecnia, Campo Grande, Mato Grosso do Sul, Brasil.

*Endereço para correspondência: leandrosamia@yahoo.com.br
}

\section{SUMMARY}

The objective of this study was to evaluate the effects of two levels of maize silage and extruded soybeans supplementation on fatty acid profile in milk fat of dairy cows. Eight Holstein cows were distributed in a double $4 \times 4$ Latin Square design with a factorial arrangement. The treatment groups were: high maize silage and low lipid, high maize silage and high lipid, low maize silage and low lipid and low maize silage and high lipid. The experimental periods lasted 21 days. Milk samples were collected on days 18 and 19 of each experimental period. The increase of lipid contents in high and low maize silage diets decreased short chain fatty acids concentrations $\left(\mathrm{C}_{4: 0}-\mathrm{C}_{12: 0}\right)$. The conjugated linoleic acid content (cis-9 trans-11 $\mathrm{C}_{18: 2}$ ) increased from 3.72 to 4.85 , and 4.6 to $5.89 \mathrm{mg} / \mathrm{g}$, when extruded soybeans was used in high and low level of corn silage, respectively. The increase in dietary lipids content resulted in higher trans-11 $\mathrm{C}_{18: 1}$ fatty acid concentration. Fatty acid trans-10 $\mathrm{C}_{18: 1}$ tended to increase with the elevation of the lipids content in the diet. There was significant correlation between trans-10, cis-12 $\mathrm{C}_{18: 2}$ and milk fat percentage. The extruded soybeans supplementation decreased short-chain fatty acids and palmitic acid in milk. In addition, this oilseed enhanced the concentration of conjugated linoleic acid $\left(\mathrm{C}_{18: 2}\right.$ cis-9 trans-11) and vaccenic acid, which improved the milk quality for the human health.

Keywords: CLA, concentrate, lipids, rumenic acid, vaccenic acid

\section{RESUMO}

Objetivou-se com este trabalho avaliar os efeitos de dois teores de silagem de milho e da suplementação com soja extrusada sobre o perfil de ácidos graxos na gordura do leite. Oito vacas da raça Holandesa foram distribuídas em um quadrado latino duplo $4 \mathrm{x}$ 4, em arranjo fatorial. Os tratamentos foram: alta silagem de milho e baixo lipídio, alta silagem de milho e alto lipídio, baixa silagem de milho e baixo lipídio e baixa silagem de milho e alto lipídio. Os períodos experimentais tiveram duração de 21 dias cada. As amostras de leite foram coletadas nos dias 18 e 19 de cada período experimental. O aumento dos teores de lipídios nos dois níveis de silagem diminuiu as concentrações de ácidos graxos de cadeia curta $\left(\mathrm{C}_{4: 0}-\mathrm{C}_{12: 0}\right)$. $\mathrm{O}$ teor de ácido linoleico conjugado (cis-9 trans-11 C18:2) aumentou de 3,72 para 4,85 , e de 4,60 para $5,89 \mathrm{mg} / \mathrm{g}$, quando a soja extrusada foi utilizada em dietas com alto e baixo nível de silagem de milho, respectivamente. $\mathrm{O}$ aumento no teor de lipídios na dieta resultou em maior concentração de trans-11 $\mathrm{C}_{18: 1 .} \mathrm{O}$ ácido graxo trans-10 $\mathrm{C}_{18: 1}$ tendeu a aumentar com a elevação do teor de lipídios na dieta. Houve correlação significativa entre trans-10, cis-12 $\mathrm{C}_{18: 2}$ e percentual de gordura do leite. A suplementação com soja extrusada diminuiu os ácidos graxos de cadeia curta e o ácido palmítico no leite. Além disso, esta oleaginosa aumentou a concentração de ácido linoleico conjugado $\left(\mathrm{C}_{18: 2}\right.$ cis-9 trans-11) e vacênico, com o aumento da qualidade do leite para o consumo humano.

Palavras-chave: ácido rumênico, ácido vaccênico, CLA, concentrado, lipídios 


\section{INTRODUCTION}

Dietary manipulation focusing on modifying milk composition can become a valuable alternative to dairy farmers, because improving milk quality may increase profitability. Most of the milk components can be manipulated by nutrition; however, the potential for change is variable among certain components, being the profile and percentage of fatty acid (FA) the most susceptible. An important goal is to optimize the FA content of these products by increasing their unsaturated fatty acids (BAUMAN \& GRIINARI 2003).

Some milk components are beneficial to human health by preventing some diseases, such as the conjugated linoleic acid (CLA). The cis-9, trans-11 $\mathrm{C}_{18: 2}$ CLA isomer or rumenic acid is the one which predominates in ruminant fat (BAUMAN \& GRIINARI 2003) and has been reported to have anticarcinogenic properties (PALMQUIST, 2010). Yet, the trans-10, cis-12 $\mathrm{C}_{18: 2}$ isomer can also be found in significant amounts in ruminant milk fat and has physiological effects on lipid metabolism, being able to reduce milk fat percentage (BAUMGARD et al., 2001).

According to Chilliard et al. (2007), the CLA content in ruminant milk depends on two processes: ruminal biohydrogenation and endogenous desaturation by the $\Delta^{9}$-desaturase enzyme. Moreover, these two processes can be influenced by the composition of the diet, the presence of $\Delta^{9}$-desaturase inhibitors, and conjugated linoleic acid supplementation.

Forage generally leads to increased levels of polyunsaturated fatty acids (PUFA) and conjugated linoleic acid in milk, and it's difficult to identify its effects because different forages are used, such as pasture, grass silage, maize silage or hay. Moreover, researches with dairy cows fed low forage diets with supplemental unsaturated fatty acid (UFA) have shown to inhibit the "de novo" FA synthesis by the mammary gland and increase CLA percentage in milk fat (GRIINARI et al., 1998). According to the authors, the inclusion of UFA in the diets enhanced accumulation of trans-10 fatty acid in the rumen.

The extruded soybeans have been used as a source of PUFA in diet of dairy cattle. Schmidely et al., (2005) observed that diets containing extruded soybeans increased the proportion of oleic, linoleic and linoleic fatty acids as opposed saturated fatty acids in dairy goats.

The main objective of this study was to evaluate the effect of two maize silage levels and extruded soybeans supplementation in the diet, on the profile of fatty acid in milk fat of dairy cows.

\section{MATERIAL AND METHODS}

The experiment was conducted at Santo Antonio Farm, located in Matozinhos, Minas Gerais, Brazil, at S- $21^{\circ} 08^{\prime} 00^{\prime \prime}$ latitude, $\mathrm{W}-44^{\circ} 15^{\prime} 40^{\prime \prime}$ longitude and annual mean temperature of $22^{\circ} \mathrm{C}$.

Eight Holstein cows, with $58 \pm 9$ days in milk (DIM) initial, average milk production of $28 \pm 4 \mathrm{~kg}$, and average BW of $650 \pm 34 \mathrm{~kg}$ were used. The animals were individually allocated in tie stall facilities. A double $4 \times 4$ latin square design was used and the treatments were distributed in a $2 \times 2$ factorial arrangement. The experimental period lasted 21 days, from the $1^{\text {st }}$ to the $14^{\text {th }}$ day animals were adapted to the diets. Milk samples were collected from four consecutive milkings during the $18^{\text {th }}$ and $19^{\text {th }}$ day of each experimental period and subjected to FA analysis. The others days were used to collect feeds and orts.

Diets were isoproteic and formulated according to the NRC (2001). The experimental treatments were: 1) high 
Rev. Bras. Saúde Prod. Anim., Salvador, v.13, n.1, p.192-203 jan/mar, 2012 http://www.rbspa.ufba.br ISSN 15199940

maize silage and low lipid levels (HMSLL), 2) high maize silage and high lipid (HMSHL), 3) low maize silage and low lipid (LMSLL), and 4) low maize silage and high lipid (LMSHL). Treatments with high and low maize silage represented 60 and $40 \%$ of the diet DM, respectively. The inclusion of extruded soybeans had the objective to increase the FA content in the experimental diets (Table 1).

Table 1. Ingredient and chemical composition of experimental diets

\begin{tabular}{lrrrr}
\hline \multirow{2}{*}{ Index } & \multicolumn{4}{c}{ Treatments } \\
\cline { 2 - 5 } & HMSLL & HMSHL & LMSLL & LMSHL \\
\hline Ingredients (\% DM) & 59.80 & 58.60 & 39.05 & 39.62 \\
\hline Maize silage & 2.52 & 4.20 & 2.22 & 2.24 \\
Soybeans hull & 12.58 & 4.10 & 15.20 & 3.07 \\
Soybeans meal & - & 14.76 & - & 17.15 \\
Extruded soybeans & 4.43 & 0.75 & 2.42 & 1.44 \\
Corn gluten meal - 60 & 15.33 & 12.98 & 25.78 & 23.95 \\
High moisture corn grain silage & 2.62 & 2.03 & 12.90 & 9.98 \\
Citrus pulp & 0.45 & 0.60 & 0.48 & 0.73 \\
Urea & 2.20 & 2.00 & 2.00 & 2.00 \\
Min.-vit. premix ${ }^{2}$ & \multicolumn{4}{c}{} \\
\hline Nutrients (\% DM) & 45.5 & 46.3 & 53.5 & 53.7 \\
\hline DM & 15.8 & 15.4 & 15.8 & 15.0 \\
CP & 46.1 & 44.2 & 40.4 & 41.7 \\
NDF & 18.5 & 17.5 & 14.4 & 15.1 \\
ADF & 39.9 & 40.1 & 42.7 & 40.5 \\
NFC & 3.7 & 6.5 & 3.8 & 6.3 \\
EE &
\end{tabular}

HMSLL $=$ high maize silage ratio and low lipid content; HMSHL $=$ high maize silage and high lipid; LMSLL $=$ low maize silage and low lipid; $\mathrm{LMSHL}=$ low maize silage and high lipid; $\mathrm{DM}=$ dry matter; $\mathrm{CP}=$ crude protein; $\mathrm{NDF}=$ neutral detergent fiber; $\mathrm{ADF}=$ acid detergent fiber; $\mathrm{NFC}=$ non-fibrous carbohydrate; $\mathrm{EE}=$ ether extract.

${ }^{1}$ min.-vit. premix: Composition per kg: Ca: $14.20 \%$; P: 4.04\%; Mg: 2.67\%; K: 0.53\%; Na: $8.37 \%$; Cl: 7.93\%; S: 1.83\%; Co: 51.3 ppm; Se: 18.89 ppm; Zn: 2662 ppm; Vit. A: 66 KIU, Vit. D: 16.4 KIU; Vit. E: 409 IU.

The total mixed ration (TMR) was offered twice daily, $60 \%$ in the morning $(6: 30 \mathrm{AM})$ and $40 \%$ in the afternoon (6:30 PM), adjusted to keep remains around $10 \%$ of the amount fed. The dry matter of the maize silage was determined weekly, using the dehydration equipment Koster (Koster Crop Tester, Strongsville,
$\mathrm{OH}$, U.S.A.), to adjust its inclusion in the TMR.

Dry matter (DM), crude protein $(\mathrm{CP})$, ether extract (EE), crude fiber (CF) and mineral matter (MM) were analyzed according to the AOAC (1990); neutral detergent fiber (NDF) and acid detergent fiber (ADF), as described by Van Soest et al. (1991). 
Non-fibrous carbohydrate $(\% \mathrm{NFC})$ was calculated by the following equation according to the NRC (2001): NFC = $100-(\% \mathrm{NDF}+\% \mathrm{CP}+\% \mathrm{EE}+\%$ Ash $)$. Milk samples were lyophilized in "Falcon" tubes. FA extraction and methylation were done according to Chouinard et al. (1999). The transmethylated samples were analyzed using a gas chromatograph (Finnigan Focus GC) with flame ionization detector, capillary column CP-Sil 88 (Varian), $100 \mathrm{~m}$ long and $0.25 \mathrm{~mm}$ internal diameter and thickness of $0.20 \mu \mathrm{m}$ (Supelco, Bellefonte, PA). Hydrogen was used as carrier gas at a flow rate of $1.8 \mathrm{~mL} / \mathrm{min}$. The program's initial oven temperature was $70^{\circ} \mathrm{C}$, held for $4 \mathrm{~min}$, increased $13^{\circ} \mathrm{C} / \mathrm{min}$ to $175^{\circ} \mathrm{C}$ and maintained for $27 \mathrm{~min}$, elevation of $4^{\circ} \mathrm{C} / \mathrm{min}$ up to $215^{\circ} \mathrm{C}$ and maintained for $9 \mathrm{~min}$ and then increase $7^{\circ} \mathrm{C} / \mathrm{min}$ up $230^{\circ} \mathrm{C}$ and lasting for $5 \mathrm{~min}$. The injector temperature was $250^{\circ} \mathrm{C}$ and detector $300^{\circ} \mathrm{C}$. Milk fat content was determined by the proximal infra-red analysis using Bentley 2000 equipment (Bentley Instruments, Chaska, U.S.A.).

The activity of $\Delta^{9}$ desaturases and elongase enzymes was determined according Pitchford et al. (2002), through mathematics indexes. The equations were:

$\Delta^{9}$-desaturase $16: \quad 100$
$[(\mathrm{C} 16: 1$ cis 9$) /(\mathrm{C} 16: 1$ cis $9+\mathrm{C} 16: 0)]$
$\Delta^{9}$-desaturase $18: \quad 100$
$[(\mathrm{C} 18: 1$ cis 9$) /(\mathrm{C} 18: 1$ cis $9+\mathrm{C} 18: 0)]$

Elongase: $\quad 100$

[(C18:0+C18 :1cis9)/(C16:0+C16 :1ci $s 9+\mathrm{C} 18: 0+\mathrm{C} 18: 1$ cis 9$)]$

Data were analyzed by the PROC MIXED procedure of SAS (SAS, 1999) according to the following model:

$\mathrm{Y}_{\mathrm{ijklm}}=\mu+\mathrm{Q}_{i}+\mathrm{P}_{j}+\mathrm{A}(\mathrm{q})_{k j}+\mathrm{F}_{l}+\mathrm{L}_{m}+$ $\left(\mathrm{F}^{*} \mathrm{~L}\right)_{l m}+\varepsilon_{i j k l m}$

Where:
$\mathrm{Y}_{\mathrm{ijklm}}=$ response of the animal $\mathrm{k}$, in period $\mathrm{j}$, inside of square $\mathrm{i}$, forage ratio 1 and lipid level $\mathrm{m}$.

$\mu=$ overall mean.

$\mathrm{P}_{j}=$ effect of period $\mathrm{j} ; \mathrm{j}=1,2,3,4$.

$\mathrm{Q}_{i}=$ effect of square $\mathrm{i} ; \mathrm{i}=1,2$.

$\mathrm{A}(\mathrm{g})_{\mathrm{kj}}=$ effect of the animal $\mathrm{k} ; \mathrm{k}=1,2$, $3,4,5,6,7,8$, inside of square $\mathrm{i}$.

$\mathrm{F}_{l}=$ effect of forage ratio $1 ; 1=$ high and low ratio.

$\mathrm{L}_{\mathrm{m}}=$ effect of lipid level $\mathrm{m} ; \mathrm{m}=$ high and low lipid levels.

$\left(\mathrm{F}^{*} \mathrm{~L}\right)_{\mathrm{lm}}=$ effect of the interaction between forage ratio and lipid level.

$\varepsilon_{i j k l m}=$ residual error.

Preplanned contrasts were used to determine the effect of maize silage, FA supplementation and interactions. Significance was declared at $\mathrm{P}<0.05$. Correlation analysis between trans-10, cis-12 content and milk FA percentage were analyzed by regression analysis using the statistical software SAS (SAS INSTITUTE, 1999).

\section{RESULTS AND DISCUSSION}

There was no effect of the interaction between maize silage and extruded soybeans supplementation in the fatty acid profile of milk (Table 2). Extruded soybeans addition reduced the concentration of short-chain fatty acid $\left(\mathrm{C}_{4: 0}\right.$ to $\left.\mathrm{C}_{12: 1}\right)$ in the high (128.79 to $96.81 \mathrm{mg} / \mathrm{g}$ ) and the low maize silage diets $(123.13$ to $92.19 \mathrm{mg} / \mathrm{g})$. The reduction of short-chain fatty acid concentration with extruded soybeans supplementation observed in this work is in agreement with those reported by Griinari et al. (1998), who found reduction of $32 \%$ on the "de novo" synthesis of FA. 
Table 2. Fatty acid composition of milk fat for cows fed different forage levels and fatty acid supplementation

\begin{tabular}{|c|c|c|c|c|c|c|c|c|}
\hline \multirow[b]{2}{*}{ Fatty acid $\mathrm{mg} / \mathrm{g}$ of fat } & \multicolumn{4}{|c|}{ Treatments $^{1}$} & \multirow[b]{2}{*}{$\mathrm{SEM}^{2}$} & \multicolumn{3}{|c|}{ Contrast } \\
\hline & HMSNES & HMSWES & LMSNES & LMSWES & & Maize Silage & $\begin{array}{l}\text { Extruded } \\
\text { Soybeans }\end{array}$ & $\mathrm{MSxL}^{3}$ \\
\hline$\overline{\mathrm{C}_{4: 0}}$ & 30.36 & 24.35 & 35.61 & 32.34 & 1.92 & $<0.01$ & 0.03 & 0.48 \\
\hline $\mathrm{C}_{6: 0}$ & 21.24 & 17.18 & 18.89 & 13.44 & 0.91 & $<0.01$ & $<0.01$ & 0.45 \\
\hline $\mathrm{C}_{8: 0}$ & 12.74 & 9.39 & 11.02 & 7.27 & 0.56 & $<0.01$ & $<0.01$ & 0.73 \\
\hline $\mathrm{C}_{10: 0}$ & 28.44 & 20.08 & 25.01 & 16.15 & 1.29 & 0.01 & $<0.01$ & 0.85 \\
\hline $\mathrm{C}_{11: 0}$ & 0.88 & 0.53 & 0.81 & 0.74 & 0.12 & 0.55 & 0.10 & 0.27 \\
\hline $\mathrm{C}_{12: 0}$ & 33.82 & 24.35 & 30.84 & 21.43 & 1.38 & 0.05 & $<0.01$ & 0.98 \\
\hline $\mathrm{C}_{12: 1}$ & 1.31 & 0.93 & 0.95 & 0.82 & 0.09 & 0.02 & 0.01 & 0.17 \\
\hline Total $C_{4: 0}-C_{12: 1}$ & 128.79 & 96.81 & 123.13 & 92.19 & 3.31 & 0.12 & $<0.01$ & 0.81 \\
\hline $\mathrm{C}_{13: 0}$ & 2.84 & 2.42 & 2.31 & 2.46 & 0.18 & 0.21 & 0.49 & 0.13 \\
\hline $\mathrm{C}_{14: 0}$ & 104.16 & 86.60 & 101.17 & 80.95 & 2.76 & 0.14 & $<0.01$ & 0.64 \\
\hline $\mathrm{C}_{14: 1}$ Cis -9 & 15.16 & 13.36 & 16.19 & 14.52 & 0.89 & 0.24 & 0.07 & 0.94 \\
\hline $\mathrm{C}_{15: 0}$ & 18.01 & 15.41 & 16.77 & 14.00 & 0.50 & 0.02 & $<0.01$ & 0.87 \\
\hline $\mathrm{C}_{16: 0}$ & 276.77 & 246.00 & 276.75 & 239.06 & 6.83 & 0.62 & $<0.01$ & 0.62 \\
\hline $\mathrm{C}_{16: 1}$ Cis -9 & 11.55 & 6.30 & 9.10 & 2.88 & 3.34 & 0.39 & 0.10 & 0.89 \\
\hline $\mathrm{C}_{17: 0}$ & 5.14 & 5.09 & 4.65 & 4.91 & 0.21 & 0.13 & 0.63 & 0.47 \\
\hline $\mathrm{C}_{17: 1}$ & 3.14 & 3.34 & 3.80 & 3.13 & 0.30 & 0.46 & 0.45 & 0.16 \\
\hline $\mathrm{C}_{18: 0}$ & 90.88 & 105.90 & 68.88 & 92.03 & 6.21 & 0.01 & $<0.01$ & 0.52 \\
\hline $\mathrm{C}_{18: 1}$ Cis -9 & 230.4 & 257.5 & 218.6 & 249.6 & 5.36 & $<0.01$ & $<0.01$ & 0.42 \\
\hline $\mathrm{C}_{18: 1}$ Trans -10 & 8.90 & 17.25 & 18.57 & 22.66 & 3.83 & 0.07 & 0.12 & 0.59 \\
\hline $\mathrm{C}_{18: 1}$ Trans -11 & 14.71 & 36.44 & 39.34 & 51.66 & 7.21 & 0.01 & 0.03 & 0.52 \\
\hline $\mathrm{C}_{18: 2}$ Trans -10 cis -12 & 0.46 & 0.62 & 0.68 & 0.79 & 0.05 & $<0.01$ & 0.02 & 0.60 \\
\hline $\mathrm{C}_{18: 2}$ Cis -9 trans -11 & 3.72 & 4.85 & 4.60 & 5.89 & 0.14 & $<0.01$ & $<0.01$ & 0.59 \\
\hline $\mathrm{C}_{18: 2}$ Cis -9 cis -12 & 32.16 & 39.04 & 44.28 & 48.97 & 1.62 & $<0.01$ & $<0.01$ & 0.50 \\
\hline $\mathrm{C}_{18: 3}$ & 4.61 & 4.87 & 3.85 & 4.11 & 0.25 & $<0.01$ & 0.31 & 1.00 \\
\hline $\mathrm{C}_{20: 0}$ & 1.65 & 1.34 & 1.80 & 1.16 & 0.18 & 0.92 & 0.02 & 0.40 \\
\hline
\end{tabular}


Bauman \& Griinari (2003) postulated theories about the reduction of the "de novo" FA synthesis in the mammary gland: acetate and $\beta$-hidroxibutirate deficiency theory; insulin-glucogenic theory; vitamin $\quad \mathrm{B}_{12} /$ metil-malonate theory; and the biohydrogenation theory. The last one has been most accepted and is based on nutritional conditions that affect ruminal fatty acid biohydrogenation with accumulation of trans $\mathrm{C}_{18: 1}$. These acids are potent inhibitors of the "de novo" fatty acid synthesis by the mammary gland. According to these authors, Baumgard et al. (2000) were the first to demonstrate that trans-10, cis-12 $\mathrm{C}_{18: 2}$ was a potent inhibitor of milk fat synthesis.
The hydrolysis and biohydrogenation of extruded soybeans lipids in the rumen produced more trans-10, cis-12 $\mathrm{C}_{18: 2}$ fatty acids (Table 2), and the inhibitors effect of de novo FA synthesis can be verified with the significant correlation $(\mathrm{P}<0.01)$ between trans -10 , cis-12 $\mathrm{C}_{18: 2}$ and milk fat percentage (Figure 1). Milk fat percentage reduced with extruded soybeans inclusion, ranging from 2.90 to $2.62 \%$ and 2.39 to $2.20 \%$ for the treatments with high maize silage and low maize silage, respectively. The increase of $1 \mathrm{mg} / \mathrm{g}$ of trans -10 , cis -12 $\mathrm{C}_{18: 2}$ content in milk fat resulted on a reduction of $2.08 \%$ in milk fat $\left(y=-2.0804 X+3.8352, r^{2}=0.396\right)$.

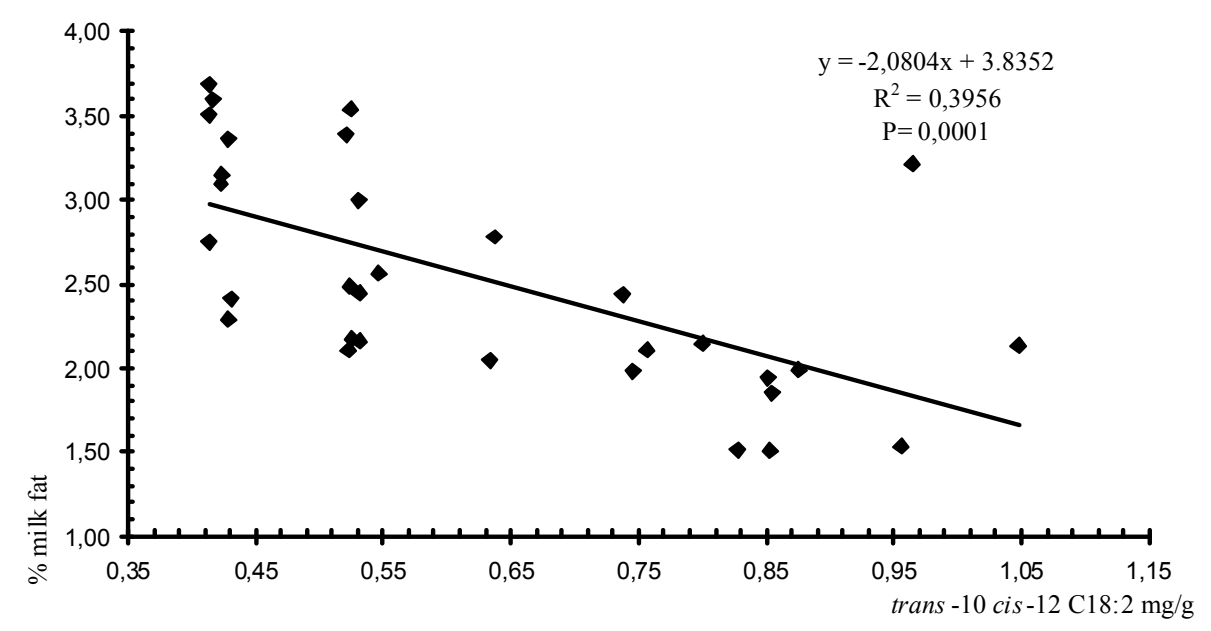

Figure 1. Relationship between milk fat percentage and $\mathrm{C}_{18: 2}$ Trans10 cis -12

Peterson et al. (2002) studied the abomasal infusion and established dose response relationship between trans-10, cis-12 $\mathrm{C}_{18: 2}$ and the reduction in milk fat with as little as $3 \mathrm{~g} / \mathrm{d}$ causing over a $20 \%$ reduction in milk fat yield.

Baumgard et al. (2001) observed that abomasal infusions of trans-10, cis-12 $\mathrm{C}_{18: 2}$ reduced milk fat percentage by $44 \%$. However, the infusion of cis- 9 trans-11 $\mathrm{C}_{18: 2} 2$ did not affect milk fat yield. The same study showed reductions of $48 \%$ of acetyl-CoA carboxilase in mammary gland cells of cows receiving infusions of trans -10 , cis-12 $\mathrm{C}_{18: 2}$, resulting in reduced milk fat yield.

Abu-Ghazaleh et al. (2002) observed similar pattern on the concentration of trans-10, cis-12 $\mathrm{C}_{18: 2}$ in milk fat and short-chain fatty acid of cows fed extruded soybeans. According to Peterson et al. (2003), the reduction of the activity of acetyl-CoA carboxilase 
occurs due the reduction of mRNA synthesis in the mammary gland. These authors also observed reductions in fatty acid sintetase and $\Delta^{9}$-desaturase mRNAs, demonstrating a wide effect of the inhibition of the "de novo" synthesis by the trans-10, cis-12 $\mathrm{C}_{18: 2}$ fatty acid isomer.

Extruded soybeans inclusion led to milk yield with better characteristics for human consumption, because the FA $\left(\mathrm{C}_{12: 0}, \mathrm{C}_{14: 0}\right.$ and $\left.\mathrm{C}_{16: 0}\right)$ associated with the incidence of atherosclerosis were reduced. However, the maize silage level did not affect medium chain fatty acid $\left(\mathrm{C}_{14}, \mathrm{C}_{15}\right.$, and $\left.\mathrm{C}_{16}\right)$, with exception of $\mathrm{C}_{15}$ which was higher in the high maize silage treatment. According to Bauman \& Griinari (2003), the palmitic acid is present in milk due to the "de novo" FA synthesis and uptake of circulating lipids. Chilliard et al. (2007) reported that, approximately $50 \%$ of the $\mathrm{C}_{16: 0}$ secreted in milk is synthesized in the mammary gland. Therefore, the results show one more time that the extruded soybeans supplementation reduced the biosynthesis in the mammary gland.

The trans- $11 \mathrm{C}_{18: 1}$ content increased with extruded soybeans addition. Also, trans$10 \mathrm{C}_{18: 1}$ percentage tended to increase by increasing the percentage of concentrate in the diet $(P=0.07)$, indicating higher supply of biohydrogenation intermediates to the mammary gland by dietary manipulation.

Jenkins et al. (2008) also reported that high amounts of lipids in the rumen, associated with changes in the ruminal ecosystem, can increase trans fatty acids. According to Kim et al. (2002), significant production of trans-10, cis-12-CLA by some Megasphaera elsdenii strains, Bifidobacterium, Propionibacterium, Lactococcus, Streptococcus, and Lactobacillus occurs in this situation.
These bacterias are also more numerous in the rumen with diets rich in concentrate and helps explain the increasing trend of trans-10 $\mathrm{C}_{18: 1}$ with reduction in levels of silage.

The CLA content (cis-9, trans-11 $\mathrm{C}_{18: 2}$ ) increased from 3.72 to $4.85 \mathrm{mg} / \mathrm{g}$, corresponding to $30.5 \%$ of increase, with the inclusion of extruded soybeans in the high maize silage diets. Diets with lower maize silage and extruded soybeans caused an increase of $28 \%$, ranging from 4.60 to $5.89 \mathrm{mg} / \mathrm{g}$. Solomon et al. (2000) observed an increase in the CLA content from 0.42 to $1.5 \mathrm{mg} / \mathrm{g}$ with diets containing $48 \%$ of forage and extruded soybeans, and Abu-Ghazaleh et al. (2002) found an increase in CLA content from 3.3 to $7.9 \mathrm{mg} / \mathrm{g}$, when fed dairy cows with diets containing $50 \%$ of forage and supplemental lipids. The increase of the CLA concentration with extruded soybeans supplementation was lower than the compared data from the literature. This lower increase may be explained by the increase of trans-10, cis-12, indicating changes in the ruminal biohydrogenation by different microbial species.

There was also an increase in the concentration of vaccenic acid (trans-11 $\mathrm{C}_{18: 1}$ ) with addition of extruded soybeans to the diets (Table 2). According to Palmquist et al. (2005), this increase is important because humans are able to convert the vaccenic acid to CLA. Turpeinen et al. (2002) reported that about $20 \%$ of dietary vaccenic acid was converted to CLA in a Finish human study. Parodi (2006) used this value to conclude that the amount of CLA available to human tissues is 1.4 times that consumed in ruminant products.

Based on that, a person ingesting about one liter of milk produced by cows fed diets with low maize silage with extruded soybeans would be ingesting 
about $22 \mathrm{~g}$ of fat, $130 \mathrm{mg}$ of CLA, and $1.12 \mathrm{~g}$ of vaccenic acid. Considering that $20 \%$ of vaccenic acid ingested is transformed in CLA, this would supply $357.3 \mathrm{mg}$ of CLA/day. In the case of the treatment high maize silage with extruded soybeans, this ingestion would be $316 \mathrm{mg} \mathrm{CLA} /$ day. According to IP et al., (2002), $300 \mathrm{mg}$ of CLA daily intake resulted in reduction of $40 \%$ of the chance to develop breast, colon, and uterus tumors. Therefore, vaccenic acid turns to be the main fatty acid responsible for the CLA supply to humans, and alternatives must be searched to increase its concentration in ruminant products. However, this fatty acid is part of the trans isomers, which are avoided by human health professionals due to its effect on cardiovascular diseases, becoming necessary its identification on foods labels.

According to Palmiquist et al. (2010), oleic acid (cis-9 $\mathrm{C}_{18: 1}$ ), considered universally to be a desirable component of dietary fat, is the second most abundant fatty acid in milk fat and its content is influenced by the dietary fat content. In this research the extruded soybeans supplementation increased the oleic acid content. A similar result occurred with the linoleic acid content.

The milk of cows fed low maize silage had higher concentrations of unsaturated fatty acids, which also provided a higher concentration of monounsaturated (MUFA) and polyunsaturated (PUFA) fatty acids (Table 3 ). This may be due the lower concentration of $\mathrm{C}_{18: 0}$ and indicates lower ruminal biohydrogenation of the fatty acids from diets when the amount of concentrate was increased. Corroborating with this explanation are the higher concentrations of $\mathrm{C}_{18: 1}$ trans-10 and trans-11 acid and also the higher concentration of linoleic and CLA. The lower ruminal biohydrogenation provided higher and better ratio unsaturated/saturated fatty acids.

Table 3. Sum and ratio of milk fat acids for cows fed with different forage levels and fatty acid supplementation ( $\%$ of fat)

\begin{tabular}{|c|c|c|c|c|c|c|c|c|}
\hline \multirow{2}{*}{$\begin{array}{l}\text { Index } \\
\text { Fatty acid }\end{array}$} & \multicolumn{4}{|c|}{ Treatments ${ }^{1}$} & \multirow{2}{*}{$\mathrm{SEM}^{2}$} & \multicolumn{3}{|c|}{ Contrast $^{3}$} \\
\hline & HMSNES & HMSWES & LMSNES & LMSWES & & $\begin{array}{l}\text { Maize } \\
\text { Silage }\end{array}$ & $\begin{array}{l}\text { Extruded } \\
\text { Soybeans } \\
\end{array}$ & $\mathrm{MSxL}^{3}$ \\
\hline Saturated & 65.83 & 59.27 & 62.32 & 56.53 & 1.62 & 0.22 & $<0.01$ & 0.56 \\
\hline Unsaturated & 34.17 & 40,73 & 37.68 & 43.47 & 0.61 & 0.04 & $<0.01$ & 0.43 \\
\hline Monounsaturated & 29.88 & 35.50 & 32.08 & 37.05 & 1.11 & $<0.01$ & $<0.01$ & 0.81 \\
\hline Polyunsaturated & 4.29 & 5.23 & 5.60 & 6.42 & 0.37 & $<0.01$ & 0.03 & 0.28 \\
\hline Unsaturated/Saturated & 0.52 & 0.69 & 0.60 & 0.77 & 0.08 & 0.02 & $<0.01$ & 0.33 \\
\hline
\end{tabular}

${ }^{1}$ HMSNES $=$ high maize silage ratio and no extruded soybeans; HMSWES $=$ high maize silage with extruded soybeans; LMSNES = low maize silage and no extruded soybeans; LMSWES = low maize silage with extruded soybeans.

${ }^{2} \mathrm{SEM}=$ standard error of the mean

${ }^{3}$ Contrasts $=$ interaction between maize silage proportion and extruded soybeans use

Treatments with high extruded soybeans supplementation showed similar results to those with higher concentrated level, i.e., lower concentration of saturated fatty acids, higher concentration of unsaturated fatty acids, monounsaturated fatty acids, 
polyunsaturated fatty acids and better ratio unsaturated/saturated fatty acids. The highest level of unsaturated fatty acids in the treatments with extruded soybeans supplementation was mainly due to the great concentration of linoleic $(51 \%)$ and oleic $(21,1 \%)$ fatty acids in extruded soybeans, that, in rumen have incomplete biohydrogenation, which will allow the intestinal absorption of these fatty acids and their unsaturated intermediates (BAUMANA \& GRIINARI, 2003).

Therefore, it can be verified that both, reduction in maize silage content, and extruded soybeans inclusion, act in a similar and beneficial way on the major fatty acids in milk.

The $\Delta^{9}$-desaturase activity can be assessed indirectly through the ratio between the pairs of fatty acids produced $\left(\mathrm{C}_{16: 1}\right.$ cis-9, $\mathrm{C}_{18: 1}$ cis-9 e CLA cis-9 trans$11)$ and their respective substrates $\left(\mathrm{C}_{16: 0}\right.$,

\author{
$\mathrm{C}_{18: 0}$ e $\mathrm{C}_{18: 1}$ trans-11) (BAUMAN \& \\ LOCK, 2006).
}

The evaluation of this activity is substantial in studies that aim to increase the CLA concentration in milk fat, due the importance of endogenous synthesis on CLA secretion (PALMQUIST et al., 2005).

In this study was observed an interaction between treatments to $\mathrm{C}_{18: 2}$ cis-9 trans-11 desaturase activity (Table 4), once that, the highest activity occurred when it was used the high maize silage and without extruded soybeans supplementation on diet. Probably the others diets provided higher $\mathrm{C}_{18: 2}$ cis-9 trans-11 intestinal absorption, which could inhibit the activity of this desaturase. Furthermore, in these diets, the trans-11 $\mathrm{C}_{18: 1}$ milk concentration was also higher, which would increase the availability of substrates to CLA endogenous synthesis.

Table 4. Index of desaturase activity involved on fatty acids metabolism and elongase of milk fat acids for cows fed with different forage levels and fatty acid supplementation $(\%$ of fat $)$

\begin{tabular}{|c|c|c|c|c|c|c|c|c|}
\hline \multirow{2}{*}{ Index } & \multicolumn{4}{|c|}{ Treatments $^{1}$} & \multirow{2}{*}{$\mathrm{SEM}^{2}$} & \multicolumn{3}{|c|}{ Contrast $^{3}$} \\
\hline & HMSNES & HMSWES & LMSNES & LMSWES & & $\begin{array}{l}\text { Maize } \\
\text { Silage }\end{array}$ & $\begin{array}{l}\text { Extruded } \\
\text { Soybeans }\end{array}$ & $\mathrm{MSxL}^{3}$ \\
\hline Desaturase $16^{\mathrm{a}}$ & 4.01 & 2.50 & 3.18 & 1,19 & 0.07 & 0.18 & $<0.01$ & 0.55 \\
\hline Desaturase $18^{\mathrm{b}}$ & 71.73 & 70.86 & 76.04 & 73.06 & 1.90 & 0.12 & 0.05 & 0.31 \\
\hline $\begin{array}{l}\text { Desaturase } \mathrm{C}_{18: 2} \\
\text { cis- } 9 \text { trans }-11^{\mathrm{c}}\end{array}$ & 20.18 & 11.75 & 10,47 & 10,23 & 0.22 & $<0.01$ & 0.04 & 0.03 \\
\hline Elongase $^{\mathrm{d}}$ & 52.70 & 59.02 & 50.14 & 58,54 & 1.58 & 0.45 & $<0.01$ & 0.67 \\
\hline
\end{tabular}

${ }^{1}$ HMSNES $=$ high maize silage ratio and no extruded soybeans; HMSWES $=$ high maize silage with extruded soybeans; LMSNES = low maize silage and no extruded soybeans; LMSWES = low maize silage with extruded soybeans.

${ }^{2} \mathrm{SEM}=$ standard error of the mean.

${ }^{3}$ Contrasts $=$ interaction between maize silage proportion and extruded soybeans use.

In a study conducted by Chilliard et al. (2001), the authors also observed lower desaturase activity when milk contained higher level of trans-11 $\mathrm{C}_{18: 1}$, which corroborates with the results of this experiment.
The lowest values found for 16 and 18 desaturase activities on diets containing extruded soybeans supplementation are attributed to the lower ratio between $\mathrm{C}_{16: 0} / \mathrm{C}_{16: 1}$ cis-9 and $\mathrm{C}_{18: 0} / \mathrm{C}_{18: 1}$ cis-9 fatty acids, respectively. Therefore, the 
highest concentration of stearic acid on milk from cows fed extruded soybeans supplementation can also have occurred by the limited $\Delta^{9}$-dessaturase activity. Chilliard et al. (2001) described that there is a limit on the conversion of unsaturated fatty acids in $\mathrm{C}_{18: 0}$. And also, there is a competition for desaturase and elongase between omega 3 and omega 6 fatty acids.

The higher activity found for elongasewith diets containing extruded soybeans, occurred because the higher intake of fatty acids may have provided higher passage of these fatty acids by rumen, allowing a higher absorption and consequently higher deposition on milk.

The extruded soybeans supplementation decreased short-chain fatty acids and palmitic acid in milk. In addition, this oilseed enhanced the concentration of CLA ( $\mathrm{C}_{18: 2}$ cis-9 trans-11) and vaccenic acid, which improved the milk quality for the human health.

Diets with lower maize silage ratio also presented higher CLA, vaccenic acid and unsaturated fatty acids content.

\section{REFERENCES}

ABU-GHAZALEH, A.A.; SCHINGOETHE, D.J.; HIPPEN, A.R.; KALSCHEUR, K.F.; WHITLOCK, L.A. Fatty Acid Profiles of Milk and Rumen Digesta From Cows Fed Fish Oil Extruded Soybeanss or Their Blend. Journal of Dairy Science, v.85, n.2266-2276, 2002.

ASSOCIATION OF OFFICIAL ANALYTICAL CHEMISTS - AOAC. Official methods of analysis. 15.ed. Arlington, Virginia. 1990, 1298p.
BAUMAN, D.E.; GRIINARI, J.M.

Nutritional regulation of milk synthesis. Annual Review of

Nutrition, v.23, p.223-237, 2003.

BAUMAN, D.E.; LOCK, A.L.

Conjugated linoleic acid: biosynthesis and nutritional significance. In: FOX, P.F.; MCSWEENEY, P.L.H. (Eds.). Advanced dairy chemistry. 3.ed. New York: Springer, 2006. v.2, p.93136.

BAUMGARD, L.H.; CORL, B.A.; DWYER, D.A.; SAEBO, A.; BAUMAN, D.E. Identification of the conjugated linoleic acid isomer that inhibits milk fat synthesis. American Journal of Physiology, v.278, p.179$184,2000$.

BAUMGARD, L.H.; SANGSTER, J.K.; BAUMAN, D.E. Milk fat synthesis in dairy cows is progressively reduced by increasing supplemental amounts of Trans-10, cis-12 conjugated linoleic acid (CLA). Journal Nutrition, v.131, p.1764-1769, 2001.

CHILLIARD, Y.; FERLAY, A.; DOREAU, M. Effect of different types of forage, animal fat or marine oils in cow's diet on milk fat secretion and composition, especially conjugated linoleic acid (CLA) and polyunsaturated fatty acids.

Livestock Production Science, v.70, p.31-48, 2001.

CHILLIARD, Y.; GLASSER, F.; FERLAY, A.; BERNARD, L.; ROUEL, J.; DOREAU, M. Diet, rumen biohydrogenation and nutritional quality of cow and goat milk fat. European

Journal of Lipid Science and Technology, v.109, p.828-855, 2007. 
Rev. Bras. Saúde Prod. Anim., Salvador, v.13, n.1, p.192-203 jan/mar, 2012 http://www.rbspa.ufba.br ISSN 15199940

CHOUINARD P.Y.; CORNEAU, L.; SAEBO, A., BAUMAN, D E. Milk yield and composition during abomasal infusion of conjugated linoleic acid. Journal of Dairy Science, v. 82, p.2737-2745, 1999.

GRIINARI, J.M.; DWYER, D.A.; MCGUIRE, M.A.; BAUMAN, D.E.; PALMQUIST, D.L.; NURMELA, K.V.V. Trans-octadecadienoic acids and milk fat depression in lactating dairy cows. Journal of Dairy Science, v.81, p.1251-1261, 1998.

IP, C.; DONG, Y.; IP, M.M.; BANNI, S.; CARTA, S.; ANGIONI, E.; MURRU, E.; SPADA, S.; MELIS, M.P. Conjugated linoleic acid isomers and mammary cancer prevention.

Nutritional Cancer, v.43, p.52-58, 2002.

JENKINS, T.C.; WALLACE, R.J.; MOATE, P.J.; MOSLEY, E.E. BoardInvited REVIEW: Recent advances in biohydrogenation of unsaturated fatty acids within the rumen microbial ecosystem. Journal of Animal Science, v.86, p.397-412. 2008.

KIM, Y.J.; LIU, R.H.; RYCHLIK, J.L.; RUSSELL, J.B. The enrichment of a ruminal bacterium (Megasphaera elsdenii YJ-4) that produces the trans10 , cis-12 isomer of conjugated linoleic acid. Journal of Applied

Microbiology, v.92, p.976-982, 2002.

NATIONAL RESEARCH COUNCIL NRC. Nutrient Requirements of Dairy Cattle. Washington, USA: National Academic Science, 2001, $381 p$.

PALMQUIST, D.L Great discoveries of milk for a healthy diet and a healthy life. Revista Brasileira de Zootecnia, v.39, p.465-477, 2010. Suppl. especial.
PALMQUIST, D.L.; LOCK, A.L.; SHINGFIELD, K.J.; BAUMAN, D. E. Biosynthesis of conjugated linoleic acid in ruminants and humans. Advances in Food Nutrition Research, v.50, p.179217, 2005.

PARODI, P.W. Conjugated linoleic acid in food. Advances in Conjugated Linoleic Acid Research, v.2, p.101122, 2006.

PETERSON, D.G.; BAUMGARD, L.H.; BAUMAN. D.E. Milk fat response to low doses of trans-10, cis12 conjugated linoleic acid (CLA). Journal of Dairy Science, v.85, p.1764-1766, 2002.

PETERSON, D.G.; MATITASHVILI, E.A.; BAUMAN, D.E. Diet-induced milk fat depression in dairy cows results in increased trans-10, cis-12 CLA in milk fat and coordinate suppression of mRNA abundance for mammary enzymes involved in milk fat synthesis. Journal of Nutrition, v.133, p.30983102, 2003.

PITCHFORD, W.S.; DELAND, M.P.B.; SIEBERT, B.D.; MALAUADULI, A.E.O.; BOTTEMA, C.D.K. Genetic variation in fatness and fatty acid composition of crossbred cattle. Journal Animal Science, v.80, p.28252832, 2002.

SAS INSTITUTE. SAS: user's guide. 6.ed. Cary, 1999.

SCHMIDELY, P.; MORAND-FEHR, P.; SAUVANT, D. Influence of extruded soybeanss with or without bicarbonate on milk performance and fatty acids composition of goat milk. Journal of Animal Science, v.88, p.757-765, 2005. 
Rev. Bras. Saúde Prod. Anim., Salvador, v.13, n.1, p.192-203 jan/mar, 2012 http://www.rbspa.ufba.br ISSN 15199940

SOLOMON, R.; CHASE, L.E.; BENGHEDALIA, D. The effect of nonstructural carbohydrate and addition of full fat extruded soybeanss on the concentration of conjugated linoleic acid in the milk fat of dairy cows.

Journal of Dairy Science, v.83, n.6, p.1322-1329, 2000.

TURPEINEN, A.M.; MUTANEN, M.; ARO, A.; SALMINEN, I.; BASU, S.; PALMQUIST, D.L.; GRIINARI, J.M. Bioconversion of vaccenic acid to conjugated linoleic acid in humans.

American Journal of Clinical

Nutrition, v.76, p.504-510, 2002.
VAN SOEST, P.J.; ROBERTSON, J.B.; LEWIS, B.A. Methods for dietary fiber, and nonstarch polysaccharides in relation to animal nutrition. Journal of Dairy Science, v.74, p.3583-3597, 1991.

Data de recebimento: 25/07/2011

Data de aprovação: 06/03/2012 